\title{
Ash Deposition in a Pulverized Coal-Fired Power Plant after High-Calcium Lignite Combustion
}

\author{
J ose-Luis Fernandez-Turiel, ${ }^{\dagger}$ Andreas Georgakopoulos, ,„‡ Domingo Gimeno," \\ Georgios Papastergios, ${ }^{\ddagger}$ and Nestoras Kolovos ${ }^{\S}$ \\ Institute of Earth Sciences J . Almera-CSIC, Sole I Sabaris s/ n, 08028 Barcelona, Spain, \\ Laboratory of Economic Geol ogy, Department of Mineralogy-Petrology-E conomic Geol ogy, \\ School of Geol ogy, Aristotle University of Thessal oniki, GR-54124, Greece, Department of \\ Geochemistry, Petrology and Geological Exploration, Faculty of Geology, University of \\ Barcel ona, Marti I Franques S/ n, 08028 Barcel ona, Spain, and Public Power Corporation of \\ Greece, Western Macedonian Lignite Center, GR-50200, Ptol emais, Greece
}

Received J anuary 28, 2004. Revised Manuscript Received May 15, 2004

\begin{abstract}
The fabric, mineralogy, and chemistry of high-calcium ash deposits from the Agios Dimitrios pulverized-lignite power plant in northern Greece have been investigated as a key to the ability to improve the performance of the power plant. All inner surfaces in the boiler are covered with a layer of particulate matter showing various degrees of agglomeration or with fouling deposits. Agglomerated fabric occurs in the lower and upper furnace sections, whereas sintered textures are mainly observed in the air heater sections. Particles in the size range of $10-50 \mu \mathrm{m}$ with no sign of large agglomeration constitute the fly ash. Calcium mineral phases are dominant in deposits (anhydrite $\left(\mathrm{CaSO}_{4}\right)$, calcite $\left(\mathrm{CaCO}_{3}\right)$, portlandite $\left(\mathrm{Ca}(\mathrm{OH})_{2}\right)$, and lime $(\mathrm{CaO})$ ); however, there are also significant amounts of silicon-containing minerals in bottom ash and fly ash (quartz $\left(\mathrm{SiO}_{2}\right)$, gehlenite $\left(\mathrm{Ca}_{2} \mathrm{Al}_{2} \mathrm{SiO}_{7}\right)$, and anorthite $\left.\left(\mathrm{CaAl}_{2} \mathrm{Si}_{2} \mathrm{O}_{8}\right)\right)$. Gas-solid reactions control deposition, without the participation of alkaline el ement compounds in the buildup of deposits. Technological modifications in the facility cannot improve the situation significantly, because of the fact that these effects are the consequence of the thermal decomposition of the high content of calcite $\left(\mathrm{CaCO}_{3}\right)$ in the feed lignite, coming from the lignite seams and the intermediate sterile layers co-excavated with the lignite. Only through improvement of the quality of the lignite during mining can the power plant improve its operations.
\end{abstract}

\section{Introduction}

Coal-fired thermal power plants use fuel from either a single source or blended coals. The decision is based on local fuel availability, fuel costs, emission limits, or technical aspects such as those associated with slagging and fouling. ${ }^{1}$ In any case, feed coal always carries inorganic matter that causes many of the technological and environmental problems attributed to coal use. Consequently, the definition of coal quality is of major importance. ${ }^{2-6}$ The content and composition (mineralogy

* Author to whom correspondence should be addressed. Telephone: (++30)-2310998514. Fax: (++30)-2310998463. E-mail address: ageorgak@geo.auth.gr.

† Institute of Earth Science, J. Almera-CSIC.

₹ Aristotle University of Thessaloniki.

" University of Barcelona.

$\S$ Public Power Corporation of Greece, Western Macedonian Lignite Center.

(1) Rushdie, A.; Sharma, A.; Gupta, R. Energy Fuels 2004, 83, 495506.

(2) Chinchon, J . S.; Querol, X.; Fernandez-Turiel, J . L.; Lopez-Soler, A. Environ. Geol. Water Sci. 1991, 18, 11-15.

(3) Querol, X.; Fernandez-Turiel, J . L.; Lopez-Soler, A. Mineral. Mag. 1994, 58, 119-133.

(4) Llorens, J . F.; Fernandez-Turiel, J . L.; Querol, X. Environ. Geol. 2001, 40, 409-416.

(5) Kolovos, N.; Georgakopoulos, A.; Filippidis. A.; Kavouridis, C. Energy Sources 2002, 24, 561-573.

(6) Finkelman, R. B. Coal-Quality I nformation-Key to the Efficient and Environmentally Sound Use of Coal, 2004. (Available via the Internet at http://energy.usgs.gov/factsheets/coalqual/coalqual.html; Search: J an-01-04). and chemistry) of inorganic matter in the coal are originally related to the geological controls of the coal deposits. 7,8 Coal deposits are composed of sedimentary sequences of coal seams interlayered with strata of other geol ogical materials (congl omerates, sandstones, clays, marls, limestones, etc.). A combination of different physicochemical geological processes (i.e., fluvioterrestrial, lacustrine, and diagenesis) define the mixture of detrital (e.g., quartz, clays) and authigenic (e.g., calcite, pyrite) mineral phases present in the deposits. ${ }^{9}$ As a result, feed coal contains a variable fraction of mineral matter that consists of inorganic material originally present in the vegetable matter, detrital material swept into the deposit during peat accumulation, and authigenic minerals precipitated as primary phases in the basin (e.g., calcite, siderite), and secondary phases disseminated or filling cavities, cracks, and cleats (e.g., calcite, pyrite, quartz, clay, sulfates) generated during coalification of the deposit. ${ }^{10}$ The geol ogical framework of coal deposits makes the co-excavation of coal with the intercalated barren layers unavoidable, substantially

(7) Querol, X.; Cabrera, L.; Pickel, W.; Lopez-Soler, A.; Hagemann, H. W.; Fernandez-Turiel, J. L. Int. J. Coal Geol. 1996, 29, 67-91.

(8) Kalaitzidis, S.; Christanis, K.; Georgakopoulos, A.; FernandezTuriel, J . L.; Papazisimou, S. Energy Fuels 2002, 16, 1476-1482.

(9) Christanis, K.; Georgakopoulos, A.; Fernandez-Turiel, J. L.; Bouzinos, A. Int. J . Coal Geol. 1998, 36, 295-313.

(10) Ward, C. R. Int. J . Coal Geol. 2002, 50, 135-168. 
increasing the inorganic matter content that is naturally present in the coal.5,11 Although coal beneficiation processes may improve the coal quality, its efficiency is not enough to totally eliminate the presence of inorganic matter in the feed fuel. Furthermore, the removal of inorganic matter may not be cost-effective or even feasible.

In addition to the inorganic matter composition and content, the utility design and operation will determine the mineral transformations during combustion and the characteristics of combustion byproducts. ${ }^{2,3,12,13}$ I norganic matter is injected in the furnace cl osely associated with the organic matter, or as free particles. Combustion conditions (temperature usually exceeding $1200{ }^{\circ} \mathrm{C}$ ) induce the liberation and fragmentation of minerals, which undergo thermal decomposition, making the persistence of the original mineral phases of feed coal very difficult. During combustion, the inorganic matter of coal is transformed to particulate matter (ash) and volatiles. Particulate matter can fall out of the general gas stream and collect on the furnace bottom (bottom ash or slag) or fly with the combustion gases through the boiler and be collected by the electrostatic precipitators (fly ash). M oreover, particulate matter and volatiles of flue gas can produce ash deposits on different parts of the facility.

Ash deposition occurs as slagging and fouling. ${ }^{13-17}$ Slagging deposits occur in the high-temperature radiant sections of the boiler and are usually associated with some degree of melting of the ash. Fouling deposits are produced in the lower-temperature convective sections of the boiler (e.g., superheaters, reheaters, and economizers) and are generally related to condensation on the low-temperaturetube surfaces, forming an adhesive film that can cause ash particles to adhere to the surface. Problems in boilers associated with ash deposits include modification of the heat transfer in different sections of the furnace, physical distortion of metal pieces due to the weight of the deposit, clogging of burners, and corrosion and erosion of metal walls.

Coal power plants are the main source of electricity in Greece, covering more than $75 \%$ of the total electric energy demand. ${ }^{18}$ Lignite is used because of the lack of domestic high-rank coals. Greece is the fifth-largest world producer of lignite and the second-largest within the European Community. There are two main coalmining districts in Greece: Western Macedonian Lignite Center (Florina-Ptolemais-Kozani basin) in northern

(11) Kolovos, N.; Georgakopoulos, A.; Filippidis, A.; Kavouridis, C. Energy Fuels 2002, 16, 1516-1522.

(12) Hurley, J . P.; Nowok, J . W.; Bieber, J . A.; Dockter, B. A. Prog. Energy Combust. Sci. 1998, 24, 513-521.

(13) Wall, T. F.; J uniper, L.; Lowe, A. ACARP Project C9055-State of-theArt Review of Ash Behavior in Coal Fired Furnaces; University of Newcastle: Newcastle, U.K., 2001; 106 pp.

(14) Raask, E. Mineral Impurities in Coal Combustion: Behavior, Problems and Remedial Measures; Hemisphere Publishing: Washington, DC, 1985; $484 \mathrm{pp}$.

(15) Benson, S. A.; J ones, M. L.; Harb, J . N. Ash Formation and Deposition. In Fundamentals of Coal Combustion for Clean and Efficient Use; Smoot, L. D., Ed.; Elsevier: New York, 1993; pp 299373.

(16) Couch, G. Understanding Slagging and Fouling in PF Combustion; IEACR/72; IEA Coal Research: London, 1994; 118 pp.

(17) Scott, D. Ash Behaviour during Combustion and Gasification: CCC/24; IEA Coal Research: London, 1999; 38 pp.

(18) Sakkas, G.; Kakaras, E.; Georgoulis, L.; Kavouridis, K. Electrical Power Generation in Greece-The Role of Lignite in Near Future 17th WEC Congress: Houston, TX, 1998; 12 pp.
Table 1. Quality of Feed Lignite of the Agios Dimitrios Power Plant during Different Time Periods ${ }^{\mathrm{a}}$

\begin{tabular}{lll}
\hline & \multicolumn{2}{c}{ average value } \\
\cline { 2 - 3 } lignite specific consumption $(\mathrm{kg} \mathrm{kW} / \mathrm{h})$ & $1993-1997$ & $1998-2000$ \\
moisture content $(\mathrm{g} / \mathrm{kg})$ & 514 & 1.73 \\
ash $(\mathrm{g} / \mathrm{kg}$, dry basis) & 342 & 509 \\
gross calorific value $(\mathrm{kJ} / \mathrm{kg})$ & 14661 & 14795 \\
net cal orific value $(\mathrm{kJ} / \mathrm{kg})$ & 5552 & 5703 \\
\multicolumn{1}{c}{ a After Kolovos et al 11} & &
\end{tabular}

Greece and Megalopolis Lignite Center in the Peloponese region in southern Greece. The quality of the recoverable lignite is closely related to the quality of the organic matter, the quality of lignite inorganic impurities, and the nature of the thin intermediate sterile layers, which are co-excavated with the lignite. 5,11,19,20 The recoverable lignite is a poor fossil fuel characterized by high moisture levels ( $\sim 550 \mathrm{~g} \mathrm{H}_{2} \mathrm{O} / \mathrm{kg}$ lignite), ash ( $\geq 300 \mathrm{~g} / \mathrm{kg}$, dry basis), low calorific value (4000-8500 kJ $/ \mathrm{kg})$, and high calcium content ( $\geq 70 \mathrm{~g} / \mathrm{kg} \mathrm{Ca}$, dry basis). ${ }^{5,18}$ Slagging and fouling severely affect the power plant's use of these lignites. The problem is serious enough to require plant shutdowns at intervals of two or three months, for cleaning purposes.

The present article is a study of the high-calcium ash deposits in the Agios Dimitrios power plant (in northern Greece) as a key to the ability to improve the performance of the lignite-fired power plant, preventing the formation of deposits and facilitating its removal. The Southern Field Mine in the Western Macedonian Lignite Center feeds the Agios Dimitrios Power Plant, which is the largest in Greece, with an installed capacity of $1585 \mathrm{MW}$ in fivelignite thermal units, producing $29 \%$ of the total electricity power. Units 1 and 2 (300 + 300 MW) were constructed in 1984, unit 3 (310 MW) in 1985, unit 4 (310 MW) in 1986, and unit 5 (365 MW) in 1997. The power plant uses pulverized coal combustion technology, which requires a drying and pulverization process before combustion. Pulverization is performed in beater wheel mills, using direct firing, where a mixture of flue gas from the furnace and air dries the lignite in the mills and then the mixture of flue gas, air, and water vapor is fed back into the furnace, together with the pulverized lignite.

\section{Lignite Characteristics}

The Southern Field lignite deposit in the Western Macedonian Lignite Center consists of multiple lignite and intermediate sterile layers that are composed primarily of marly limestones and carbonaceous marls and secondarily by clays and sands. The co-excavation of lignite and intermediate sterile layers increases the calcite $\left(\mathrm{CaCO}_{3}\right)$ content of lignite, which increases the ash content and decreases the calorific value of the mined lignite. Quality parameters of lignite burnt in the Agios Dimitrios Power Plant are shown in Table 1. The mineral content of the feed lignite is $\sim 350 \mathrm{~g} / \mathrm{kg}$ and

(19) Georgakopoulos, A.; Fernandez-Turiel, J . L.; Filippidis, A. Llorens, J . F.; K assoli-Fournaraki, A.; Querol, X.; Lopez-Soler, A. Trace Element Contents of the Lava Xylite/Lignite and Ptolemais Lignite Deposits, Macedonia County, Greece. In Coal Science; Pajares, ]. A., Tascón, J . M. D., Eds.; Coal Science and Technology, 24; Elsevier: New York, 1995; pp 163-166. 602. 


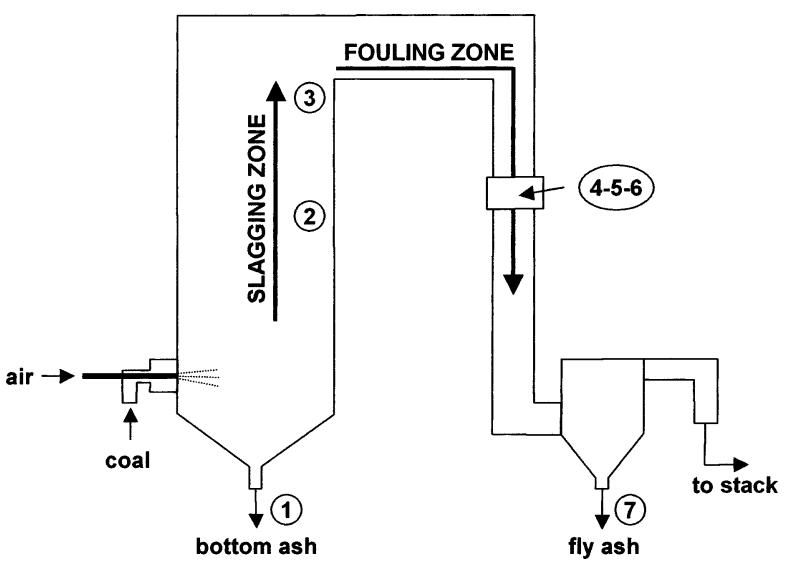

Figure 1. Pulverized coal furnacelayout, showing the sample locations.

consists of calcite (316 g/kg), clays (illite and kaol inite) $(26 \mathrm{~g} / \mathrm{kg})$, feldspars $(4 \mathrm{~g} / \mathrm{kg})$, and quartz $(4 \mathrm{~g} / \mathrm{kg})$. According to these parameters, special attention was given during plant operation to the control of inorganic impurities and especially to cal cium carbonate mineral content reduction to achieve better power-plant operations, in terms of ash deposit generation and $\mathrm{CO}_{2}$ emission. ${ }^{11}$

\section{Materials and Methods}

Seven samples were collected in Thermal Unit 1 of the Agios Dimitrios Power Plant, which reflects the main types of ash deposits that occur in the combustion facility. This unit, which has a capacity of $300 \mathrm{MW}$, was completed in 1984 and is composed of a Stein boiler and an Alsthom T/G set. Locations of sampling points are schematically indicated in Figure 1. Sampling was performed with the unit out of service, because of maintenance.

A scanning electron microscopy (SEM) system (J EOL model J SM-840) that was equipped with an AN-10.000 LINK X-ray energy dispersive system (EDS) was operated at $20 \mathrm{kV}$ to examine ash textures and to obtain semiquantitative information on composition. The dry samples were placed on the brass support by covering the contact surface and side faces with silver paste dissolved by acetone. In the case of the powdered samples, the particulate matter was first secured using double coated adhesive tape and then connected via a patch of silver paint to enhance conductivity. Finally, the samples were sputter-coated with gold. Crystalline minerals were identified by powder X-ray diffraction (XRD), using a SIEMENS model D-500 X-ray diffractometer (scintillation counter, graphite secondary monochromator, $\mathrm{Cu} \mathrm{K} \alpha$ radiation, $20 \mathrm{kV}, 40 \mathrm{~mA}$ ) using the EVA 3.09 software. Step scans were performed over the range of $2^{\circ}-70^{\circ} 2 \theta$, with stepping intervals of $0.05^{\circ}$ and a count time of $5 \mathrm{~s}$. Quantification was performed using the reference intensity method. ${ }^{3} \mathrm{M}$ ajor and trace element concentrations were determined in ash deposit samples by inductively coupled plasma-mass spectrometry (ICP-MS) and inductively coupled plasma-optical emission spectrometry (ICP-OES) ${ }^{4}$

\section{Results and Discussion}

All inner surfaces in the unit are covered with a layer of particulate matter of various degrees of agglomeration or with bonded deposits. The ashes show different characteristics, depending on their location in the unit, because of differences in temperature and the composition of the particulate matter and volatiles of the flue gas.
The bottom ash from the furnace hopper (sample 1) falls out of suspension or from the furnace surface walls. It also includes material falling from deposits above the burner region, and especially from the superheater ash deposits (i.e., from the locations of samples 2 and 3, respectively). This deposit consists of milimetric-centimetric aggl omerates of dark gray color (this is due to the occurrence of an important content of unburned lignite). Some aggl omerates are white. This material is friable. SEM-EDX examination showed agglomerates that are composed of particles of unburned coal and inorganic matter, generally $<10 \mu \mathrm{m}$ in size (Figure 2 ). The inorganic particles have a varied composition, with calcium as the dominant cation, and minor amounts of silicon, aluminum, and iron. The main inorganic components are calcite $\left(\mathrm{CaCO}_{3}\right)$, high-calcium glass, and quartz ( $\mathrm{F}$ igures 3 and 4); anhydrite $\left(\mathrm{CaSO}_{4}\right)$, anorthite $\left(\mathrm{CaAl}{ }_{2} \mathrm{Si}_{2} \mathrm{O}_{8}\right)$, and kaolinite $\left.) \mathrm{Al}_{2} \mathrm{Si}_{2} \mathrm{O}_{5}(\mathrm{OH})_{4}\right)$ are present as minor mineral phases.

Ash deposits above the burner region (sample 2 ) come from the hottest zone in the furnace $\left(800-1200{ }^{\circ} \mathrm{C}\right)$. These deposits are hard, with a beige-colored surface, and show fresh fractures. They consist of a framework of anhydrite $\left(\mathrm{CaSO}_{4}\right)$ crystals with agglomerates of irregular particles of glass (see Figure 2). In addition, XRD patterns show minor contents of calcite $\left(\mathrm{CaCO}_{3}\right)$ and hematite $\left(\mathrm{Fe}_{2} \mathrm{O}_{3}\right)$. EDX analysis confirms the presence of minor amounts of silicon, aluminum, and iron in the glass (see Figures 3 and 4).

The deposits in the superheater tube banks at the furnace exit (the section exposed to temperatures of $400-700^{\circ} \mathrm{C}$ ) consist of friable aggregates of particulate matter (sample 3; see Figure 2). The white col or of the samples at this location denotes the absence of unburned lignite particles. This feature differentiates these deposits from the bottom ash, despite the fact that the former and the inorganic yield of the latter are practically identical, relative to the minerals present and their chemical compositions (Figures 3 and 4). Another difference is their kaolinite $\left(\mathrm{Al}_{2} \mathrm{Si}_{2} \mathrm{O}_{5}(\mathrm{OH})_{4}\right)$ content, which was not detected in sample 3 .

The deposits observed in the air heater section are formed at temperatures of $300-400{ }^{\circ} \mathrm{C}$. They are massive, very hard in comparison with previously described deposits, and occur bonded to metal walls and tubes. Three types have been observed macroscopically. The first is a massive deposit with no internal structure, showing concoidal fractures (very bright in fresh fractures), and is brown in color (sample 4). The second is a deposit that shows thin bands of brownish colors (sample 5). The third is a banded deposit consisting of white and brown al ternating layers (sample 6). Similar XRD patterns are shown by other banded deposits (samples 5 and 6), whereas the massive sample 4 is characterized by higher contents of anhydrite $\left(\mathrm{CaSO}_{4}\right)$ and lower contents of lime ( $\mathrm{CaO})$ (see Figures 3 and 4). Banded textures were also observed via SEM (see Figure 2). EDX analysis shows only dominant peaks of calcium and minor amounts of silicon, aluminum, iron, and magnesium (the latter only in sample 4), with no major differences within a layer or among layers observed in the analysis of mixed submicrometer-sized particles (the spatial resolution of the EDS that was 

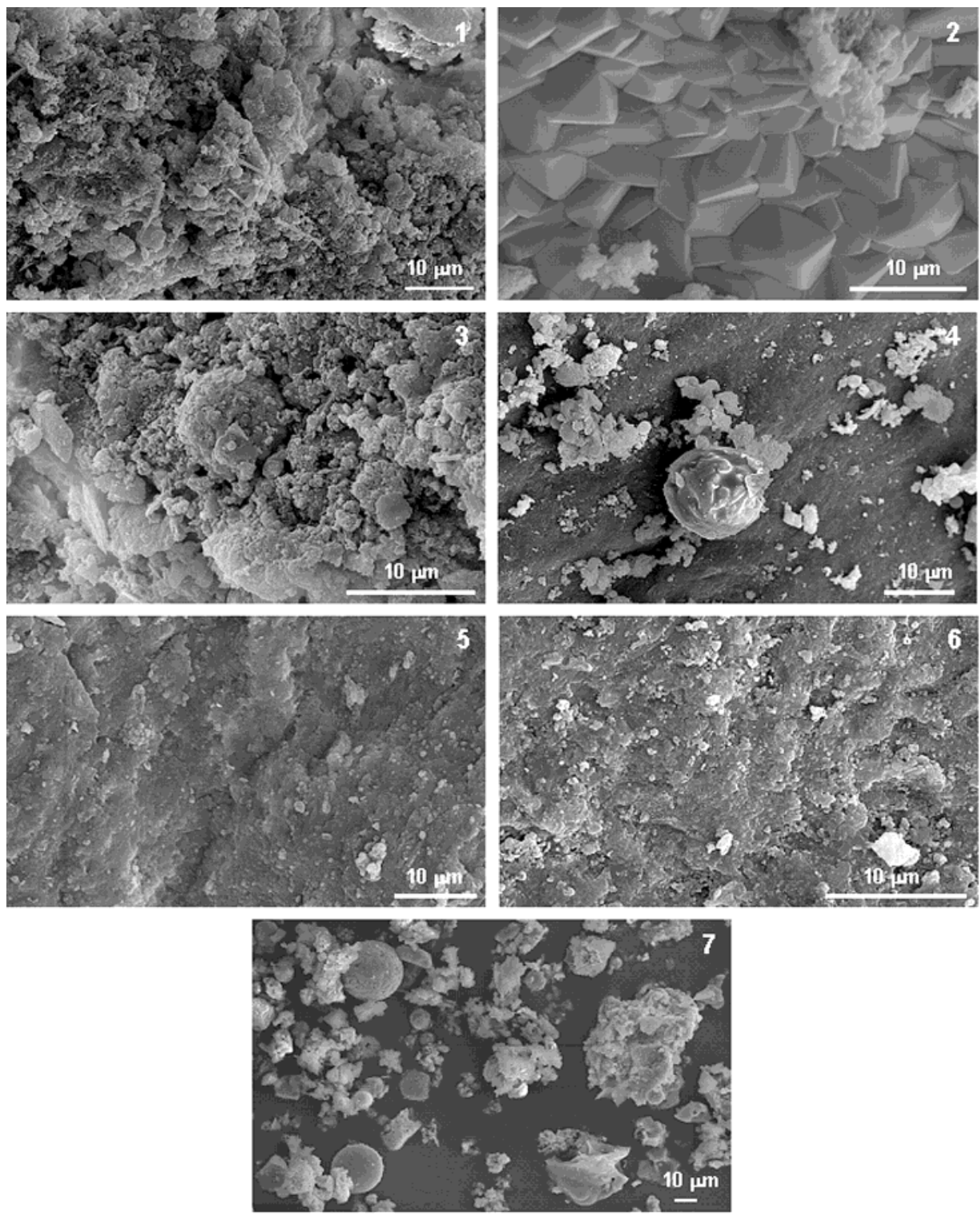

Figure 2. Scanning electron microscopy (SEM) secondary-el ectron images of the studied ash deposits (image numbers correspond to the sample locations identified in Figure 1): (1) agglomerates of particulate matter from the furnace bottom hopper; (2) framework of anhydrite $\left(\mathrm{CaSO}_{4}\right)$ crystals with agglomerates of irregular particles of glass from deposits above the burner region; (3) agglomerates of particulate matter from the superheater tube banks at the furnace exit; (4) sintered layered deposit from the air heater section, showing adhered glass agglomerates and a sphere on the outer surface; (5 and 6) sintered layered deposits from the air heater section; (7) fly ash. In image 7 of Figure 2, the sphere in the upper left area shows a framework that probably is that of calcium aluminate $\left(\mathrm{CaAl}_{2} \mathrm{O}_{4}\right)$.

used is $\sim 1 \mu \mathrm{m})$. These banded deposits show high contents of lime $(\mathrm{CaO})$ and portlandite $\left(\mathrm{Ca}(\mathrm{OH})_{2}\right)$, which are absent in the furnace deposits. Spheres and agglomerates of irregular particles of glass have been observed adhered to the outer surface of some deposits (see Figure 2). The spheres show a framework that is probably composed of calcium al uminate $\left(\mathrm{CaAl}_{2} \mathrm{O}_{4}\right)$, as suggested by the calcium and aluminum contents observed via EDX. The glass associated with these skel etons contains calcium, silicon, aluminum, and iron. The low content of calcium aluminate is not enough to confirm this phase using XRD; however, similar phases have been observed after experimental calcination of $\mathrm{Al}_{2} \mathrm{O}_{3}$ and $\mathrm{CaCO}_{3}{ }^{21}$

Finally, the fly ash is a macroscopic white-gray powder. The samples were collected from an electrostatic precipitator (ESP) hopper. Temperatures in the
ESP are in the range of $40-80^{\circ} \mathrm{C}$. This ash consists of $90 \%$ particle clusters $<50 \mu \mathrm{m}$ in size (although generally $<10 \mu \mathrm{m})$ and $10 \%$ spheres with a diameter of $10-20$ $\mu \mathrm{m}$ (see Figure 2). Particle clusters are generally composed of submicrometer-sized crystals. It is important to note the role of silicon-rich phases in the fly ash in contrast with samples 4, 5, and 6. In addition to the calcium phases observed in the air heater section (anhydrite $\left(\mathrm{CaSO}_{4}\right)$, calcite $\left(\mathrm{CaCO}_{3}\right)$, portlandite (Ca$\left.(\mathrm{OH})_{2}\right)$, lime $(\mathrm{CaO})$, and probably calcium aluminate $\left(\mathrm{CaAl}_{2} \mathrm{O}_{4}\right)$ ), sample 7 shows a high content of quartz $\left(\mathrm{SiO}_{2}\right)$ and minor amounts of gehlenite $\left(\mathrm{Ca}_{2} \mathrm{Al}_{2} \mathrm{SiO}_{7}\right)$ and anorthite $\left(\mathrm{CaAl}_{2} \mathrm{Si}_{2} \mathrm{O}_{8}\right)$ (see Figures 3 and 4 ).

(21) Aguilar, J.; Arato, A.; Hinojosa, M.; Ortiz, U. Synthesis of $\mathrm{MgAl}_{2} \mathrm{O}_{4}$ at Low Temperature with $\mathrm{CaCO}_{3}$ Additions. In Advanced Structural Materials; Calderon-Benavides, H. A., Cabanas-Moreno, G., Eds.; Materials Science Forum, Vol. 442; Trans Tech Publications, Inc.: Uetikon-Zurich, Switzerland, 2003; pp 79-84. 


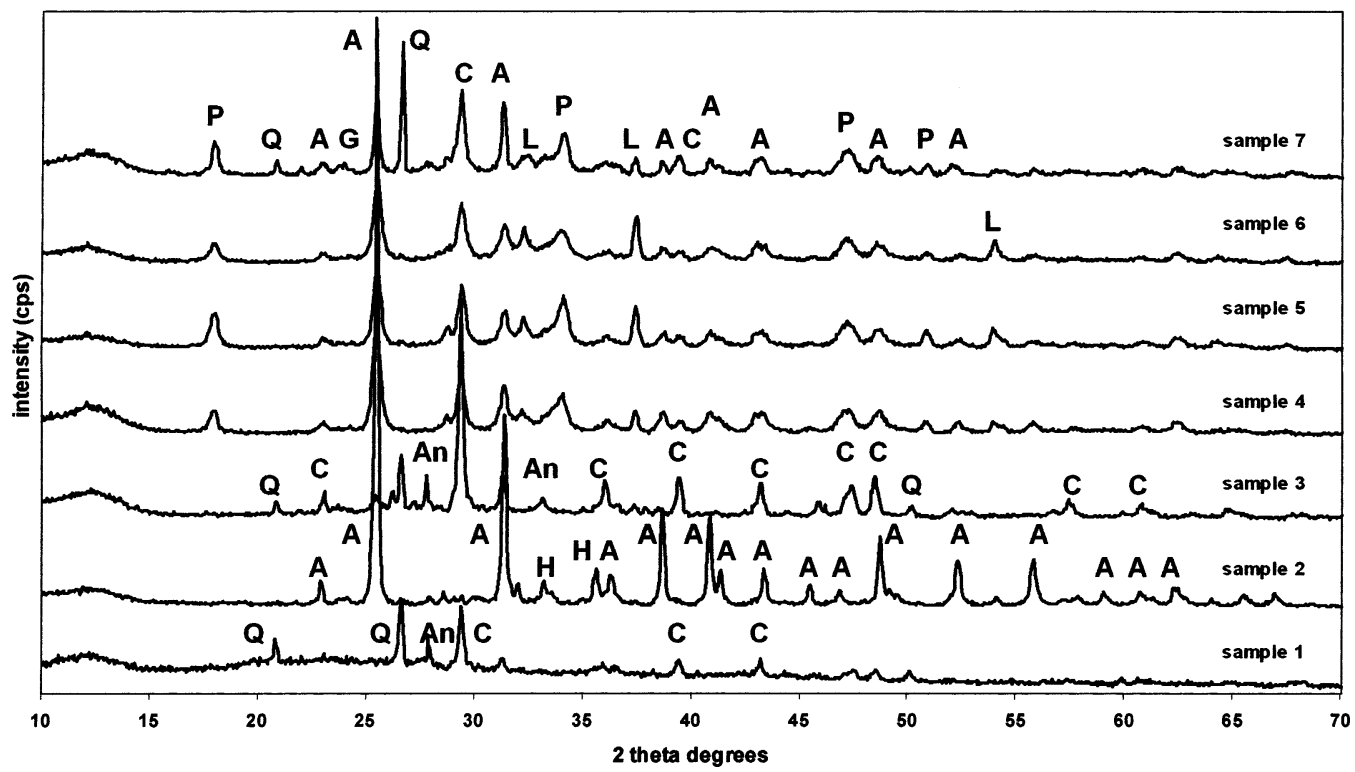

Figure 3. X-ray diffraction (XRD) patterns of the studied ash deposits (sample numbers correspond to those given in $\mathrm{Figure} \mathrm{1;}$ intensity is shown in counts per second (cps)): peak identifications are as follows: $\mathrm{A}$, anhydrite $\left(\mathrm{CaSO}_{4}\right) ; \mathrm{An}$, anorthite $\left(\mathrm{CaAl}{ }_{2}-\right.$ $\left.\mathrm{Si}_{2} \mathrm{O}_{8}\right) ; \mathrm{C}$, calcite $\left(\mathrm{CaCO}_{3}\right) ; \mathrm{G}$, gehlenite $\left(\mathrm{Ca}_{2} \mathrm{Al}_{2} \mathrm{SiO}_{7}\right) ; \mathrm{H}$, hematite $\left(\mathrm{Fe}_{2} \mathrm{O}_{3}\right)$; L, lime $(\mathrm{CaO}) ; \mathrm{P}$, portlandite $\left(\mathrm{Ca}(\mathrm{OH})_{2}\right) ;$ and Q, quartz $\left(\mathrm{SiO}_{2}\right)$.

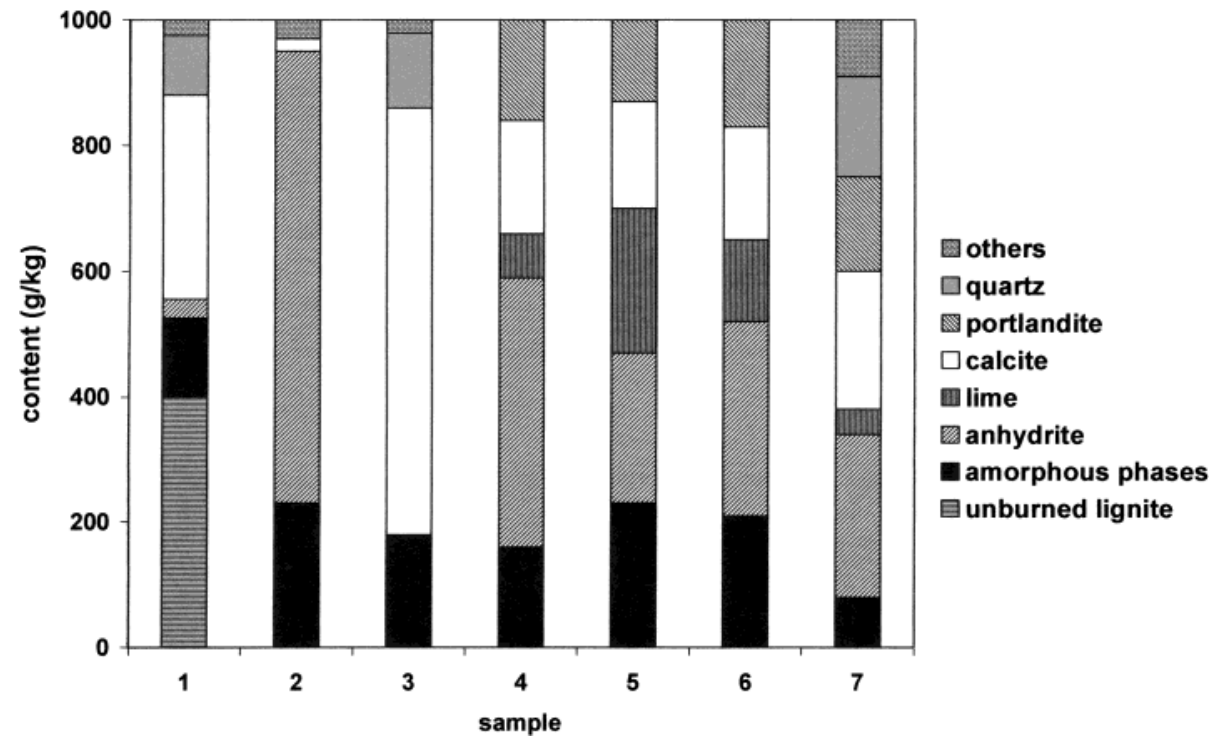

Figure 4. Ash mineral composition. The term "others" includes the minor contents of anorthite $\left(\mathrm{CaSO}_{4}\right), \mathrm{gehlenite}\left(\mathrm{Ca}_{2} \mathrm{Al}{ }_{2} \mathrm{SiO}{ }_{7}\right)$, and hematite $\left(\mathrm{Fe}_{2} \mathrm{O}_{3}\right)$. See Figure 3 for XRD patterns.

In summary, calcium mineral phases dominate in the ash deposits that have been studied. Deposits with an agglomerated fabric occur in the lower and upper furnace sections, whereas sintered textures are mainly observed in the air heater sections. Particles with the size range of $10 \mu \mathrm{m}$ with no sign of large aggl omeration constitute the fly ash.

The observed fabrics and mineral compositions indicate that the formation processes of the studied ash deposits are quite different from those usually described for low-calcium coals (or high-silicon-aluminum-iron coals). In fact, high-calcium lignite combustion is more similar to fluidized bed combustion (FBC) than to lowcalcium coal conventional combustion. ${ }^{22-26}$ The cal cites of feed lignite and FBC sorbent have comparable rol es, with the furnace temperature acting as an intermediate between the conventional and the FBC combustion.
The high content of unburned lignite in the bottom ash (sample 1) is due to the low combustion efficiency prior to unit shutdown for cleaning. The other unburned elements that are observed in this ash are composed of calcite, quartz, feldspar, and, in minor amounts, kaolinite. The new phases generated are practically restricted to high-calcium amorphous minerals (glass). This glass acts as "glue" at the furnace operation

(22) J uan, R.; Ruiz, C.; Andres, J . M.; Querol, X.; Fernandez-Turiel J. L. FBC Fouling Deposits from Aragon Coals. In Coal Science; Pajares, J . A., Tascón, J. M. D., Eds.; Coal Science and Technology 24 Elsevier: New York, 1995; pp 667-670

(23) Anthony, E. J .; Granatstein, D. L. Prog. Energy Combust. Sci. 2001, 27, 215-236.

(24) Garcia-Labiano, F.; Abad, A.; de Diego, L. F.; Gayán, P.; Adanez, I. Chem. Eng. Sci. 2002, 57, 2381-2393.

(25) Zhou, J. C. J .; Liu, J .; Zhou, Z.; Huang, Z.; Cao, X.; Zhao, X.; Cen, K. Prog. Energy Combust. Sci. 2003, 29, 381-405. 169 

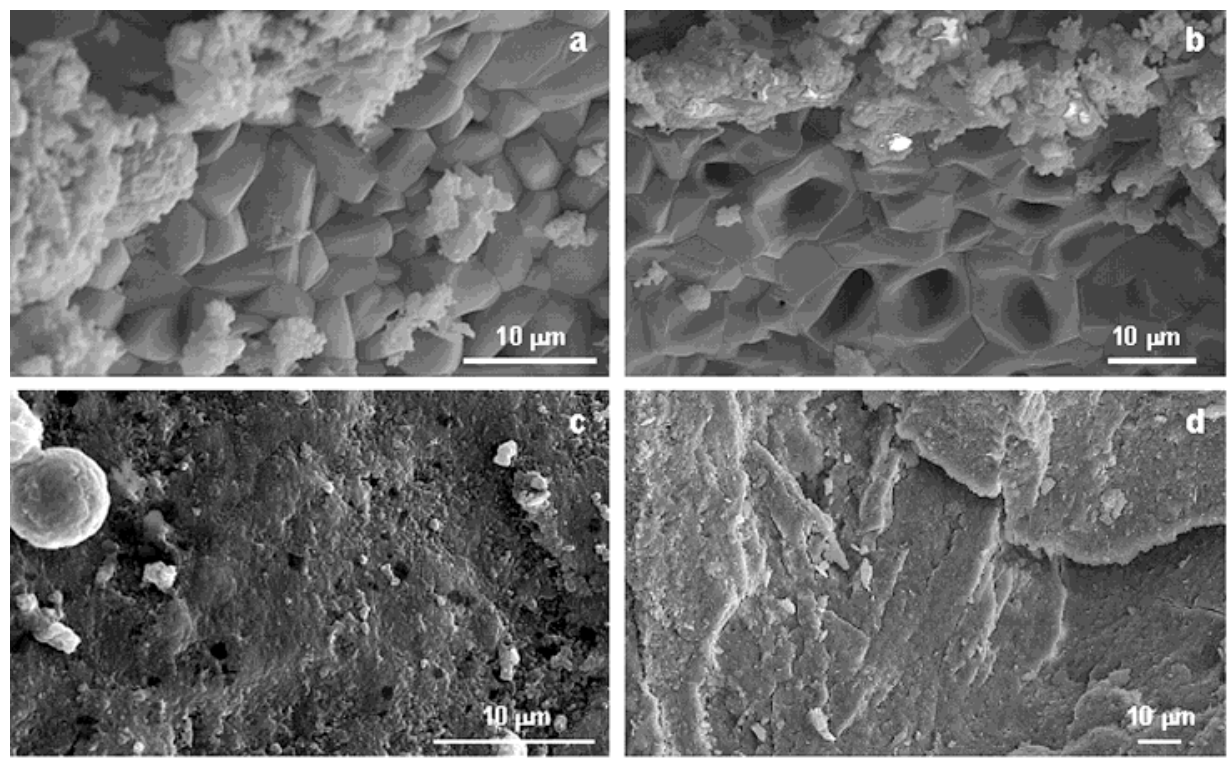

Figure 5. SEM secondary-electron images showing, in the upper part, (a) a framework of anhydrite $\left(\mathrm{CaSO}_{4}\right) \mathrm{crystals}$ with agglomerates of irregular particles of high-calcium glass from deposits above the burner region and (b) the rounding of crystals probably via a gas-solid reaction. Lower images illustrate deposits from the air heater section; the left image (panel c) is an example of a massive sintered deposit, whereas the right image (panel d) shows the detail of the layered fabric of sample 5 . Note the difference in porosity.

temperature, agglomerating the unburned and semiburned particles ( $<100 \mu \mathrm{m}$ in size) that remain after combustion. This process is particularly effective during and after the fallout of suspended particles below the burner section and in the superheater tube banks at the furnace exit. However, there is no unburned coal at the furnace exit, because of the pass of the material through the hottest zone in the furnace $\left(800-1200{ }^{\circ} \mathrm{C}\right)$, located over the burner region, before reaching the exit.

In the previously mentioned hottest area in the central section of the furnace, combustion products from the burners expand and fill the furnace duct on their passage to the exit plane. The temperature of particles in the free gas stream of the combustion gases exceed $1200{ }^{\circ} \mathrm{C}$. The temperature gradient varies slowly toward the walls; however, near the wall, this trend changes fast, as the temperature decreases to $800{ }^{\circ} \mathrm{C}$.

Ash deposition may initiate with the attachment of small dry particles of anhydrite $\left(\mathrm{CaSO}_{4}\right)$ to the wall, probably generated by the condensation of volatile components. These submicrometer-sized particles act as a nucleus for the growth of anhydrite crystals, such as those observed in Figure 2. In addition, some incidental agglomerates of glass particles (>10 $\mu \mathrm{m}$ ) may impact inertially onto the anhydrite surface. These particles could be sticky or, if there is noliquid phase, may adhere as dry particles by electrostatic forces. ${ }^{15}$ The chemical nature of the particles also has a role; compounds that contain calcium and sulfur are among those that form strong bonds. Moreover, the adherence of submi crometer-sized particles is greatly enhanced by the surface chemistry of oxidized steel. Steel furnaces experience a progressive nonporous scaling of iron oxides that is due to the oxidizing nature of flue gases. ${ }^{13}$ Residues of iron oxides (hematite, $\mathrm{Fe}_{2} \mathrm{O}_{3}$ ) were identified via XRD in sample 3. Because of these phenomena, condensation products generally deposit uniformly over the surface, whereas impacted particles are irregularly distributed, depending on the fluid dynamics and distribution of ash in the gas stream. ${ }^{1}$ The high temperatures and strong turbulence make the environment relatively unstable and, as a consequence, the deposits can be modified. Figure 5 shows the rounding of crystal edges, which may be the result of a gas-solid reaction. Similar features have been described in FBC of petroleum coke. ${ }^{27}$ There is no evidence of liquid running off the surface, as is frequently observed in low-calcium coal combustion, where the deposit surface becomes molten and flows, and the deposit growth stops. ${ }^{1}$ Although no melting is produced in the studied unit, the process is equivalent to slagging in non-calcium-rich coal combustion, because of the generation of hard deposits, which cause similar problems (e.g., modification of heat transfer in this section of the furnace and physical distortion of metal pieces).

The deposits observed in the lower-temperature convective sections of the boiler (as the sampled deposits in the air heater section) are quite similar to the fouling deposits produced in low-calcium coal combustion utilities. Therefore, formation processes are al so comparable. However, it is widely accepted that the initial layer of fouling deposits consists of $\mathrm{Na}-\mathrm{K}$ salts. ${ }^{13}$ This situation does not occur in the Greek lignite under consideration, because of the low alkali concentrations, as evidenced by ICP-OES/ICP-MS (see Table 2) and SEM-EDX analysis. Theinitiation of fouling deposits for this lignite is thought to be principally related to bonds between calcium-fluxed oxides and the boiler wall oxide layers, producing a particulate deposit of calcium-rich amorphous phases and lime ( $\mathrm{CaO})$. Utility boilers fired with high-calcium coals develop fouling deposits at much lower temperatures than those observed when lowcalcium coals are burned. ${ }^{12,28,29}$ Sulfur oxide $\left(\mathrm{SO}_{2}\right), \mathrm{CO}_{2}$, and $\mathrm{H}_{2} \mathrm{O}$ in the flue gas react with the particulate

(27) I ribarne, J . V.; Anthony, E. J .; I ribarne, A. Fuel Process Technol. 2003, 82, 27-50.

(28) Hurley, J. P.; Benson, S. A. Energy Fuels 1995, 9, 775-781.

(29) Anthony, E. J .; J ia, L. Fuel 2000, 79, 1933-1942. 
Table 2. Composition of the Studied Ash Deposits (Based on the Locations Identified in Figure 1) ${ }^{\text {a }}$

\begin{tabular}{crrrrrrr}
\hline & \multicolumn{7}{c}{ Composition $(\mathrm{g} / \mathrm{kg})$} \\
\cline { 2 - 8 } component & \multicolumn{1}{c}{1} & \multicolumn{1}{c}{2} & \multicolumn{1}{c}{4} & \multicolumn{1}{c}{5} & \multicolumn{1}{c}{6} & \multicolumn{1}{c}{7} \\
\hline $\mathrm{CaO}$ & 110.2 & 328.6 & 285.6 & 431.4 & 449.8 & 458.5 & 374.0 \\
$\mathrm{MgO}$ & 19.9 & 21.4 & 32.4 & 42.4 & 33.7 & 36.9 & 35.5 \\
$\mathrm{SiO}$ & 343.1 & 143.5 & 469.7 & 212.7 & 270.6 & 247.7 & 350.8 \\
$\mathrm{Al}_{2} \mathrm{O}_{3}$ & 74.0 & 29.2 & 110.2 & 37.8 & 45.9 & 39.6 & 88.0 \\
$\mathrm{Na}_{2} \mathrm{O}$ & 4.3 & $<0.1$ & 1.2 & $<0.1$ & $<0.1$ & $<0.1$ & 1.0 \\
$\mathrm{~K}_{2} \mathrm{O}$ & 4.6 & 1.2 & 4.5 & 1.2 & 2.0 & 2.0 & 6.9 \\
$\mathrm{Fe}_{2} \mathrm{O}_{3}$ & 22.0 & 89.7 & 38.6 & 36.2 & 33.0 & 35.6 & 40.7 \\
$\mathrm{TiO}_{2}$ & 3.7 & 1.8 & 5.6 & 2.9 & 2.9 & 4.7 & 4.7 \\
$\mathrm{P}_{2} \mathrm{O}_{5}$ & 1.7 & 2.5 & 3.2 & 3.1 & 3.0 & 3.3 & 3.3 \\
$\mathrm{SO}_{3}$ & 15.4 & 371.6 & 29.1 & 207.2 & 147.6 & 169.4 & 84.0
\end{tabular}

a Legend for table data is as follows: (1) bottom ash, (2) deposit above the burner region, (3) agglomerates of particulate matter from the superheater tube banks at the furnace exit, $(4,5$, and 6$)$ sintered deposits from the air heater section, and (7) fly ash.

deposit, forming anhydrite $\left(\mathrm{CaSO}_{4}\right)$, calcite $\left(\mathrm{CaCO}_{3}\right)$, and portlandite $\left(\mathrm{Ca}(\mathrm{OH})_{2}\right)$. In addition, these reactions induce the sintering of the deposit. F or example, anhydrite $\left(\mathrm{CaSO}_{4}\right)$ is formed by the sulfation of cal cium from glass and from lime $(\mathrm{CaO})$, with an activation energy that is lower (and a reaction rate that is higher) in the former case. ${ }^{12}$ Within the confined volume of each particle, this sulfation leads to increases in molar volume and possibly pressure, which cements the adjacent particles (the molar volumes of lime $(\mathrm{CaO})$ and anhydrite $\left(\mathrm{CaSO}_{4}\right)$ are 16.9 and $46.0 \mathrm{~cm}^{3} / \mathrm{mol}$, respectively). On the other hand, carbonate formation is known to be much faster than sulfation in FBC boilers. ${ }^{30}$ In time, cohesion and strength, which devel op with the linking of the particles, consolidate the deposit into a hard mass. Sintering among particles leads to the development of masses where the individual particles have become undistinguishable (SEM examination shows sintered submicrometer-sized particles; see Figures 2 and 5). Cohesion may destroy original fabrics (such as the layered structures of samples 5 and 6), resulting in massive textures (see sample 4). This evolution is accompanied by the decrease of amorphous phases and lime (CaO) (Figure 4).

Particulate matter and volatiles not separated from the gas or deposited on system surfaces arrive, as they are carried through the boiler by flowing gas, at sections (e.g., ESPs) where the temperature is excessively low $\left(<80^{\circ} \mathrm{C}\right)$ and, there, generate sintering or agglomeration. As a result, the fly ash is composed of isolated particles and small particle clusters on the order of $10-50 \mu \mathrm{m}$ in size, showing no integration into larger units (see Figure 2). The fraction of spheres is lower than fly ash from low-calcium combustion, because of the lower temperature and the higher-calcium composition.

Although the main cation involved in the ash formation of the studied boiler is calcium, silicon also has an important role. In addition to calcium phases, only silicon minerals have been observed in significant amounts. In some cases, the presence of quartz in fly ash is interpreted as having survived the combustion process. ${ }^{12,31} \mathrm{~A}$ fraction of the quartz observed in bottom

(30) Iisa, K.; Tullin, C.; Hupa, M. In Proceedings of the Eleventh International Conference on FBC; Anthony, E. J ., Ed.; ASME: Montreal, Canada, 1991; pp 83-90. ash (sample 1) and fly ash (sample 7) may have this origin (especially in bottom ash); however, the formation of neomorphic quartz is also possible. The occurrence of other siliceous phases in fly ash $(90 \mathrm{~g} / \mathrm{kg}$ of gehlenite $\left(\mathrm{Ca}_{2} \mathrm{Al}_{2} \mathrm{SiO}_{7}\right)$ and $30 \mathrm{~g} / \mathrm{kg}$ of anorthite $\left.\left(\mathrm{CaAl}_{2} \mathrm{Si}_{2} \mathrm{O}_{8}\right)\right)$ is evidence of the involvement of silicon in several reactions. In relation to the resistance of some minerals to combustion, some calcite may also survive calcination during combustion, because of the short residence time of the particles in the flame, which does not heat long enough to decompose the interior of large calcite particles. ${ }^{31}$ Calcite may remain as unreacted cores that are covered with lime $(\mathrm{CaO})$ and/or anhydrite $\left(\mathrm{CaSO}_{4}\right)^{32}$

\section{Conclusions}

The high-calcium lignite from the Southern Field deposit in the Western Macedonian Lignite Center (in northern Greece) severely deteriorates power-plant operations, because of agglomeration and fouling effects. Technological modifications in the facility cannot improve the situation significantly, because these effects are the consequence of the thermal decomposition of the feed lignite calcite $\left(\mathrm{CaCO}_{3}\right)$ that originates from the lignite seams and the intermediate sterile layers co-excavated with the lignite. Increasing the lignite quality during mining (reducing the calcite content) is the best solution to improve the power-plant operation.

Fabrics and composition of the studied ash deposits are more closely related to deposits that are produced in fluidized bed combustion (FBC) than to those generated in conventional combustion of low-calcium coals. Deposits with an agglomerated fabric occur in the lower and upper furnace sections, whereas fouling deposits with sintered textures are mainly observed in the air heater section. Particles in the range of $10-50 \mu \mathrm{m}$ with no signs of large agglomeration constitute the fly ash. Calcium mineral phases are dominant, but there are significant amounts of silicon minerals (in bottom ash and fly ash). The formation of ash deposits is closely associated with gas-solid reactions. No liquid phases seem to contribute to either the adhesion to walls or the joining of particles together. On the other hand, alkaline el ement compounds have no role in the buildup of deposits.

Acknowledgment. The authors would like to thank the assistance provided by the Aristotle University of Thessaloniki, the University of Barcelona (especially, the Scientific-Technical Survey), and the Institute of Earth Sciences, J aume AImera-CSI C. The authors also thank Prof. Dr. M. Garcia-Valles for invaluable collaboration in the XRD work.

\section{EF 0400161}

(31) Demir, I.; Hughes, R. E.; DeMaris, P. J . Fuel 2001, 80, 16591673 163.
(32) Laursen, K.; Duo, W.; Grace, J . R.; Lim, J . Fuel 2000, 79, 153- 